\title{
Cool-season turfgrass color and growth calibrated to leaf nitrogen
}

Salvatore S. Mangiafico

University of California

Karl Guillard

University of Connecticut - Storrs, karl.guillard@uconn.edu

Follow this and additional works at: https://opencommons.uconn.edu/plsc_articles

Part of the Plant Sciences Commons

\section{Recommended Citation}

Mangiafico, Salvatore S. and Guillard, Karl, "Cool-season turfgrass color and growth calibrated to leaf nitrogen" (2007). Plant Science Articles. 23.

https://opencommons.uconn.edu/plsc_articles/23 


\title{
Cool-Season Turfgrass Color and Growth Calibrated to Leaf Nitrogen
}

\author{
Salvatore S. Mangiafico and Karl Guillard丸
}

\begin{abstract}
Tissue $\mathrm{N}$ analysis a tool available for $\mathrm{N}$ management of turfgrass. However, peer-reviewed calibration studies to determine optimum tissue $\mathrm{N}$ values are lacking. A field experiment with a mixed cool-season species lawn and a greenhouse experiment with Kentucky bluegrass (Poa pratensis L.) were conducted across $2 \mathrm{yr}$, each with randomized complete block design. Treatments were $\mathrm{N}$ application rates between 0 and $587 \mathrm{~kg} \mathrm{~N}$ ha $^{-1} \mathrm{yr}^{-1}$. In the field experiment, clipping samples were taken monthly from May to September, dried, ground, and analyzed for total N. Clippings samples were collected one to two mowings after plots were fertilized. Linear plateau models comparing relative clipping yield, Commission Internationale de l' Eclairage hue, and CM1000 index to leaf $\mathrm{N}$ concentrations were developed. In the greenhouse experiment, clipping samples were taken every 2 wk from May to October and composited across sample dates for leaf $\mathrm{N}$ analysis. Color and clipping yields were related to leaf $\mathrm{N}$ concentrations using linear plateau models. These models indicated small marginal improvements in growth or color when leaf $\mathrm{N}$ exceeded $30 \mathrm{~g} \mathrm{~kg}^{-1}$, suggesting that a leaf $\mathrm{N}$ test can separate turf with optimum leaf $\mathrm{N}$ concentrations from turf with below optimum leaf $\mathrm{N}$ concentrations. Plateaus in leaf $\mathrm{N}$ concentrations with increasing $\mathrm{N}$ fertilizer rates suggest, however, that this test may be unable to identify sites with excess available soil $\mathrm{N}$ when turf has been mowed before tissue sampling.
\end{abstract}

S.S. Mangiafico, Dep. of Environmental Sciences, Univ. of California, Riverside, CA 92521; K. Guillard, Dep. of Plant Science, Unit 4067, Univ. of Connecticut, 1376 Storrs Rd., Storrs, CT 06269-4067. Received 20 Apr. 2006. *Corresponding author (karl.guillard@uconn.edu).

Abbreviations: CIE, Commission Internationale de l' Eclairage.

There ARE FEW tools available for turfgrass managers in humid 1 climates to guide $\mathrm{N}$ fertilization. Nitrogen fertilizer applications to turfgrass are typically guided by scheduled application timings and rates, or by expected improvements in visual quality. Overfertilization may result if suboptimum visual quality is erroneously attributed to $\mathrm{N}$ deficiency. Likewise, scheduled applications and rates typically do not take into account plant available $\mathrm{N}$ added to the soil by organic matter mineralization, returned clippings, atmospheric deposition, irrigation water, or residual mineral $\mathrm{N}$ from previous applications. Fertilizer applied without consideration of these other sources may result in an excess application of $\mathrm{N}$, increasing the potential for $\mathrm{N}$ losses. For example, increased nitrate $\left(\mathrm{NO}_{3}-\mathrm{N}\right)$ leaching from creeping bentgrass (Agrostis stolonifera L.) was noted when clippings were returned but $\mathrm{N}$ rates were not decreased accordingly (Kopp and Guillard, 2005). Visual assessment of turf may not reliably distinguish sites with moderately excess $\mathrm{N}$ from those with sufficient $\mathrm{N}$. It would be desirable, therefore, to base $\mathrm{N}$ management decisions on some measured soil or plant parameter rather than on scheduled applications, set rates, or expected improvements in visual quality.

Potential tools for $\mathrm{N}$ management of turfgrass include measuring soil $\mathrm{NO}_{3}-\mathrm{N}$ with anion exchange membranes, measuring salt-extractable soil $\mathrm{NO}_{3}-\mathrm{N}$, and assessing turf color with handheld reflectance meters. Studies have suggested that soil $\mathrm{NO}_{3}-\mathrm{N}$

Published in Crop Sci. 47:1217-1224 (2007)

doi: 10.2135/cropsci2006.04.0259

(C) Crop Science Society of America

677 S. Segoe Rd., Madison, WI 53711 USA

All rights reserved. No part of this periodical may be reproduced or transmitted in any form or by any means, electronic or mechanical, including photocopying, recording, or any information storage and retrieval system, without permission in writing from the publisher. Permission for printing and for reprinting the material contained herein has been obtained by the publisher. 
desorbed from anion exchange membranes may serve to separate turfgrass sites that would be responsive to additional $\mathrm{N}$ application from nonresponsive sites (Kopp and Guillard, 2002b; Mangiafico and Guillard, 2005, 2006), but this technique has not been widely adopted for use in turfgrass management. Similarly, salt extractable soil $\mathrm{NO}_{3}-$ $\mathrm{N}$ concentration may be used to determine $\mathrm{N}$ sufficiency in perennial grassland sites (Collins and Allinson, 2004), but the use of a soil $\mathrm{NO}_{3}-\mathrm{N}$ test has not been adequately explored for turfgrass. Correlations between reflectance meter measurements and visual color, visual quality, tissue N, or chlorophyll concentration (Trenholm et al., 1999; Landschoot and Mancino, 2000; Rodriguez and Miller, 2000; Mangiafico and Guillard, 2005) suggest that reflectance meters may be used to guide $\mathrm{N}$ fertilization of turf, but this application also has not been sufficiently explored. While these methods show potential for $\mathrm{N}$ management of turfgrass, their uses are limited because there are few studies exploring their applications in turfgrass. They may become widely adopted in the future if further study confirms their practicality, and turfgrass industry professionals and soil testing laboratories embrace them.

A currently available tool for $\mathrm{N}$ management of turfgrass is leaf tissue $\mathrm{N}$ analysis. Plant tissue analysis for $\mathrm{N}$ is often available at commercial and government-run soil and plant testing laboratories, and tissue analysis may help to identify management problems not indicated by a soil test. Minimum tissue $\mathrm{N}$ concentrations for adequate growth have been established for some cool-season grasses managed as forage, including Kentucky bluegrass (Poa pratensis L.), perennial ryegrass (Lolium perenne L.), and tall fescue (Festuca arundinacea Schreb.). Minimum adequate N concentrations for herbage range from 26 to $28 \mathrm{~g} \mathrm{~kg}^{-1}$ for Kentucky bluegrass, from 23 to $35 \mathrm{~g} \mathrm{~kg}^{-1}$ for perennial ryegrass, and from 28 to $32 \mathrm{~g} \mathrm{~kg}^{-1}$ for tall fescue (Kelling and Matocha, 1990; Pinkerton et al., 1997). Because these species are subjected to different management regimes when grown as forage crops than when grown as turfgrass; however, it is not certain that these minimum adequate ranges would be appropriate for turfgrass. A sufficiency range for clippings $\mathrm{N}$ concentration has been reported for turfgrass, from 27.5 to $35.0 \mathrm{~g} \mathrm{~kg}^{-1}$ (Jones, 1980; Turner and Hummel, 1992). However, this range was based on general observations, and no indication was given as to turf species, climate, or management practices from which the data were derived. Differences in tissue $\mathrm{N}$ concentration of clippings among species and cultivars were found under similar management conditions (Liu et al., 1993; Liu and Hull, 2006). A single range of optimum values for tissue $\mathrm{N}$ concentration may not be applicable to all turf species or all growing conditions. Ranges of clippings $\mathrm{N}$ concentrations have been given for a survey of healthy turf: 24 to $83 \mathrm{~g} \mathrm{~kg}^{-1}$ for creeping bentgrass, 34 to $47 \mathrm{~g}$ $\mathrm{kg}^{-1}$ for tall fescue, 33 to $51 \mathrm{~g} \mathrm{~kg}^{-1}$ for perennial ryegrass, and 25 to $51 \mathrm{~g} \mathrm{~kg}^{-1}$ for Kentucky bluegrass (Mills and Jones, 1996). Averages of clippings $N$ concentration from a survey of healthy turf were $37 \mathrm{~g} \mathrm{~kg}^{-1}$ for creeping red fescue (Festuca rubra L.) and $54 \mathrm{~g} \mathrm{~kg}^{-1}$ for Kentucky bluegrass (Mills and Jones, 1996). These ranges and averages, however, were not compared with turf growth or quality and were not presented as optimum ranges.

We are aware of no peer-reviewed field calibration studies that compared grass growth or quality to leaf $\mathrm{N}$ concentrations to determine optimum ranges for grasses grown under turfgrass management conditions. One study that compared turf growth to $\mathrm{N}$ concentration reported a linear increase in perennial ryegrass growth with increasing assimilated- $\mathrm{N}$ concentration in clippings (from $\sim 30$ to $>50 \mathrm{mg} \mathrm{N} \mathrm{g}^{-1}$ ), but reported no plateau in growth at high assimilated-N concentrations (Bowman, 2003). Because the turf was grown as a hydroponic culture and received frequent $\mathrm{N}$ applications, however, it is not known if these results would suggest an optimum range applicable to turf grown under field conditions.

Studies reporting $\mathrm{N}$ concentrations for well-nourished turf may give some indication of expected optimum tissue $\mathrm{N}$ concentrations. For a mixed species lawn receiving 392 $\mathrm{kg} \mathrm{N} \mathrm{yr}{ }^{-1}$, tissue $\mathrm{N}$ concentrations were typically between 40 and $50 \mathrm{~g} \mathrm{~kg}^{-1}$ by the end of the growing season (Kopp and Guillard, 2002a), but reported tissue $\mathrm{N}$ concentrations were $>50 \mathrm{~g} \mathrm{~kg}^{-1}$ for this treatment on some sample dates, and $<20 \mathrm{~g} \mathrm{~kg}^{-1}$ for the same treatment on other sample dates. Similarly, while tissue $\mathrm{N}$ concentrations were typically between 39 and $51 \mathrm{~g} \mathrm{~kg}^{-1}$ for $\mathrm{N}$-fertilized perennial ryegrass turf, tissue $\mathrm{N}$ concentrations were as high as $61 \mathrm{~g}$ $\mathrm{kg}^{-1}$ on some sample dates and as low as $34 \mathrm{~g} \mathrm{~kg}^{-1}$ on other sample dates for similarly fertilized treatments (Miltner et al., 2001). Tissue $\mathrm{N}$ concentrations were typically between 40 and $49 \mathrm{~g} \mathrm{~kg}^{-1}$ for a creeping bentgrass turf fertilized with urea, but on one sampling date were as high as 74 $\mathrm{g} \mathrm{kg}^{-1}$ (Davis and Dernoeden, 2002). Reported tissue N concentrations higher than an expected optimum range may be a result of luxury consumption, especially when studies report values for total N, which includes unassimilated $\mathrm{N}$ compounds. Luxury consumption is defined as an increase in tissue concentration of a nutrient by absorption from the growing medium, when the increase doesn't correspond to a further increase in plant growth (Epstein, 1972). For turf, this definition may be amended to include other plant responses such as color, density, or recovery from injury. Cultural management factors and the timing of tissue sampling relative to fertilization may also affect tissue $\mathrm{N}$ concentration. Some reported concentrations may not be representative of optimum tissue $\mathrm{N}$ but may be the result of excess available $\mathrm{N}$ or particularly ideal conditions for $\mathrm{N}$ uptake, either coupled with luxury consumption. Calibration studies directly comparing turf growth or quality to $\mathrm{N}$ concentrations are needed to confidently 
identify optimum ranges without inflation due to luxury consumption or date-specific conditions.

Other field studies reporting tissue $\mathrm{N}$ concentrations averaged across sampling dates for $\mathrm{N}$ fertilized turf reported 36, 43 to 45, and $38 \mathrm{~g} \mathrm{~kg}^{-1}$ for Kentucky bluegrass (Wesley et al., 1988; Liu et al., 1993; Frank et al., 2006, respectively), and 41 to 44 and 36 to $39 \mathrm{~g} \mathrm{~kg}^{-1}$ for perennial ryegrass and tall fescue respectively (Liu et al., 1993). Since these values are averages across sampling dates, their application as optimum concentrations may be limited. Greenhouse studies have reported tissue $\mathrm{N}$ concentrations as high as $58 \mathrm{~g} \mathrm{~kg}^{-1}$ for perennial ryegrass (Bowman et al., 1989; Bowman and Paul, 1992; Bowman, 2003), and as high as $51 \mathrm{~g} \mathrm{~kg}^{-1}$ for creeping bentgrass (McCrimmon et al., 1992). Because these studies were conducted under greenhouse conditions, in some cases of short duration, and in some cases employing hydroponically grown turf, it is not certain that these values would be applicable to field conditions.

Tissue $\mathrm{N}$ analysis holds promise as a tool for $\mathrm{N}$ management of turfgrass. However, optimum levels for turfgrass tissue $\mathrm{N}$ have not been validated with calibration studies. This study was conducted to identify optimum leaf tissue $\mathrm{N}$ concentrations for growth and color responses of a mixed cool-season species lawn in Connecticut.

\section{MATERIALS AND METHODS Field Experiment Design and Management}

A field experiment was conducted at the University of Connecticut Plant Science Teaching and Research Farm in Storrs, CT, during two consecutive growing seasons (2003 and 2004). Twenty-seven field plots, each measuring $1.5 \times 1.5 \mathrm{~m}$, were arranged in a randomized complete block design. Treatments consisted of nine rates of $\mathrm{N}$ application. Each month, from May to October, each plot received 0, 4.9, 9.8, 19.6, 29.4, 39.1, 48.9, 73.4 , or $97.9 \mathrm{~kg} \mathrm{~N} \mathrm{ha}^{-1}$, for a total of between 0 and $587 \mathrm{~kg} \mathrm{~N}$ $\mathrm{ha}^{-1} \mathrm{yr}^{-1}$, applied as $\mathrm{NH}_{4} \mathrm{NO}_{3}$. Phosphorus (P) as triple superphosphate and potassium $(\mathrm{K})$ as $\mathrm{KCl}$ were applied equally to all plots twice yearly according to soil test recommendations. A total of $174 \mathrm{~kg} \mathrm{P} \mathrm{ha}^{-1}$ and $252 \mathrm{~kg} \mathrm{~K} \mathrm{ha}{ }^{-1}$ were applied during the experiment. Soil $\mathrm{pH}$ remained greater than 6.0 throughout the duration of the experiment. Plots were mowed weekly during the growing season to a height of $4.5 \mathrm{~cm}$ and clippings remained on the plots. No irrigation was added to supplement natural precipitation, and turf did not undergo dormancy during summer months.

The site had been seeded to $34 \%$ creeping red fescue (variety unstated), 15\% 'Cutter' perennial ryegrass, 15\% 'Elf' perennial ryegrass, and 30\% Kentucky bluegrass (variety unstated), by weight, in 1999. The stand remained in turf since then, receiving $98 \mathrm{~kg} \mathrm{~N} \mathrm{ha}^{-1} \mathrm{yr}^{-1}$ and treated to prevent weed infestation, before this study. The species composition of the stand at the commencement of this experiment was not recorded, but the seeded species remained the dominant plants, in about equal proportion. The native soil was a Paxton fine sandy loam (Coarse-loamy, mixed, active, mesic Oxyaquic Dystrudepts).
At the beginning of our experiment the upper $15 \mathrm{~cm}$ of the soil profile had a $\mathrm{pH}$ of 6.1 , organic matter concentration of 52.9 $\mathrm{g} \mathrm{kg}^{-1}$ by loss on ignition (Ball, 1964), and $1.32 \mathrm{mg} \mathrm{kg}^{-1} 0.01$ $M \mathrm{CaCl}_{2}$ extractable $\mathrm{NO}_{3}-\mathrm{N}$. Twice during the experiment, fenoxaprop \{2-[4-[(6-chloro-2-benzoxazolyl)oxy]phenoxy]pro panoic acid $\}$ and quinclorac (3,7-dichloro-8-quinolinecarboxylic acid) were applied to all plots to control annual grass weeds and broadleaf weeds, respectively.

\section{Greenhouse Experiment Design and Management}

A greenhouse study was conducted with a similar design as the field experiment but with different soil, turf species, and irrigation regime. Sixty-four intact soil columns were arranged in randomized complete block design and seeded to Kentucky bluegrass (60\% 'Midnight', 20\% 'Apollo', 20\% 'Rambo') (LESCO, Strongsville, $\mathrm{OH}$ ). Treatments consisted of 16 rates of $\mathrm{N}$ fertilization: $0,4.9,9.8,14.7$ 19.6, 24.5, 29.3, 34.2, 39.1, 44.0, 48.9, $58.7,68.5,78.2,88.0$, and $97.8 \mathrm{~kg} \mathrm{~N} \mathrm{ha}^{-1} \mathrm{mo}^{-1}$ from May to October 2003 and 2004, for a total of between zero and $587 \mathrm{~kg}$ $\mathrm{N} \mathrm{ha}{ }^{-1} \mathrm{yr}^{-1}$. Nitrogen was applied as aqueous $\mathrm{NH}_{4} \mathrm{NO}_{3}$.

Soil columns of an Agawam fine sandy loam (coarse-loamy over sandy or sandy-skeletal, mixed, active, mesic Typic Dystrudepts) were obtained in 1998 for use in an experiment concerning nitrate leaching from creeping bentgrass (Kopp and Guillard, 2005). Each column measured $76.2 \mathrm{~cm}$ tall by 20.3 $\mathrm{cm}$ i.d. Schedule 40 PVC pipe was cut into sections, driven into the soil, and excavated to obtain undisturbed soil columns. In the greenhouse, each column was fitted with high-density polyethylene funnels lined with glass fabric and pea stone to prevent soil loss but allow percolate water to drain. At the beginning of our experiment, the upper $10 \mathrm{~cm}$ of the soil had a $\mathrm{pH}$ of 6.9 , organic matter concentration of $29.1 \mathrm{~g} \mathrm{~kg}^{-1}$ (Ball, 1964), and $5.52 \mathrm{mg} \mathrm{kg}^{-1} 0.01 \mathrm{M} \mathrm{CaCl}_{2}$ extractable $\mathrm{NO}_{3}-\mathrm{N}$ after initial fertilization at seeding.

In April 2003 and April 2004, columns were seeded with Kentucky bluegrass at a rate of $196 \mathrm{~kg}$ seed ha ${ }^{-1}$. Nitrogen as aqueous $\mathrm{NH}_{4} \mathrm{NO}_{3}$ was applied at seeding at a rate of $12.2 \mathrm{~kg}$ $\mathrm{N} \mathrm{ha}^{-1}$, and irrigation was then applied daily at a rate of 0.4 $\mathrm{cm} \mathrm{d}^{-1}$ until the turf was established. After turf establishment, irrigation was applied at $2.5 \mathrm{~cm} \mathrm{wk}^{-1}$ from May to November. Phosphorus as aqueous $\mathrm{KH}_{2} \mathrm{PO}_{4}$ and $\mathrm{K}$ as aqueous $\mathrm{KH}_{2} \mathrm{PO}_{4}$ and aqueous $\mathrm{KCl}$ were applied equally to all columns four times during the experiment according to soil test recommendations, for a total of $170 \mathrm{~kg} \mathrm{P} \mathrm{ha}^{-1}$ and $292 \mathrm{~kg} \mathrm{~K} \mathrm{ha}^{-1}$. Soil pH remained greater than 6.5 throughout the experiment. Turf was grown in a greenhouse under natural light. A whitewash shading compound (Continental Products Co., Euclid, $\mathrm{OH}$ ) was applied each April and removed each October, resulting in a 38\% reduction in incoming light during this period. Automated controls in the greenhouse were set for heating when temperatures were below $16^{\circ} \mathrm{C}$ and cooling when temperature was greater than $24^{\circ} \mathrm{C}$. Hydrogen dioxide (Biosafe Systems, Glastonbury, CT) was applied regularly throughout the experiment to turf leaves, and propiconazole $\{1[[2-(2,4-$ dichlorophenyl)-4-propyl-1,3-dioxolan-2-yl]methyl]-1H-1,2,4-triazole\} (Syngenta, Corp., Basel, Switzerland) was applied in May 2004, both for the control of powdery mildew (Erysiphe graminis f.sp. hordei). Imidacloprid \{1[(6-chloro-3-pyridinyl)methyl]-N-nitro-2-imidazolidinimine\} 
(Olympic Horticultural Products, Brandenton, FL) was applied in July 2004 to control fungus gnats (Bradysia spp.).

\section{Leaf Nitrogen, Hue, CM1000 Index, and Clipping Yield}

In the field experiment, turfgrass clipping samples were taken once per month from May through September, 2003 and 2004, for a total of 10 sample dates. Clippings samples were collected 12 to 18 $\mathrm{d}$, or one to two mowings, after plots were fertilized. Leaf blades were clipped from a $470-\mathrm{cm}^{2}$ area of a plot, collecting all tissue above $4.5 \mathrm{~cm}$ from the soil surface. Clippings were dried at $71^{\circ} \mathrm{C}$ for $48 \mathrm{~h}$ and weighed. These weights were used as clipping yield measurements. These clippings were ground in a UDY Cyclone mill (UDY Corp., Fort Collins, CO) to pass through a $0.5-\mathrm{mm}$ screen and analyzed for total $\mathrm{N}$ by persulfate digestion (Purcell and King, 1996) and subsequent $\mathrm{NO}_{3}-\mathrm{N}$ determination on a Scientific Instruments continuous flow analyzer (WESTCO, Danbury, CT) by the Griess-Ilosvay method (Keeney and Nelson, 1982). For each digestion, a digestion check sample of nicotinic acid of known weight and $\mathrm{N}$ concentration was used to ensure complete digestion and recovery of organic $\mathrm{N}$.

Commission Internationale de l'Eclairage (CIE) hue measurements of turfgrass were taken within $9 \mathrm{~d}$ after the clipping samples, using a Minolta CR400 chroma meter (Konica Minolta Holding, Tokyo, Japan). A greater hue value implies a greener color in the range of data presented in this paper. For each measurement, leaf blades were clipped from a small section of each plot, collecting all tissue above $4.5 \mathrm{~cm}$ from the soil surface. Clippings were laid flat into an optically dense stack, and a color measurement was taken in CIE $\mathrm{L}^{\star} \mathrm{a}^{\star} \mathrm{b}^{\star}$ coordinates at illuminant condition C (Hunter and Harold, 1987). The leaf blades were then randomly rearranged in the stack and another measurement was taken. This was repeated for five measurements for each plot. Values of $a^{\star}$ and $b^{\star}$ were averaged per plot and converted to CIE hue values (McGuire, 1992).

Reflectance measurements were taken with the Spectrum CM1000 chlorophyll meter (Spectrum Technologies, Plainfield, IL). Index measurements from this meter have been correlated to chlorophyll concentration in turfgrass (Mangiafico and Guillard, 2005). Ten measurements per plot of the turf canopy were taken with the Spectrum CM1000 and averaged per plot. Measurements were taken in full sun between 1000 and $1400 \mathrm{~h}$ with the meter facing away from the sun and when the surfaces of turf leaves were dry. Measurements were taken holding the meter approximately $1.5 \mathrm{~m}$ from the turf canopy, yielding a circular area of evaluation of approximately $180 \mathrm{~cm}^{2}$ per measurement.

In the greenhouse experiment, CIE hue and CM1000 measurements of turfgrass were taken every $2 \mathrm{wk}$, from May to October for a total of 24 sample dates. CM1000 measurements were taken holding the meter approximately $30 \mathrm{~cm}$ from the turf canopy, yielding a circular area of evaluation of approximately $1.3 \mathrm{~cm}^{2}$ per measurement. Turf was clipped to a height of $3.8 \mathrm{~cm}$ every $2 \mathrm{wk}$ within $2 \mathrm{~d}$ of hue and CM1000 measurements. All clippings were collected, dried, weighed, and ground. Ground clipping samples were composited for each column across all sample dates and analyzed for total $\mathrm{N}$ by persulfate digestion and subsequent $\mathrm{NO}_{3}-\mathrm{N}$ determination, as described in the field experiment.

\section{Statistical Analyses}

For the field experiment, clipping yield was plotted against leaf $\mathrm{N}$ concentration and a linear plateau model consisting of a linear segment and a plateau segment $[y=a+b x, x \leq(\mathrm{CC}) ; y=a$ $+b(\mathrm{CC}), x>(\mathrm{CC})$, where CC, the critical concentration, is the value on the $x$ axis where the segments join] was developed for each sample date. With this model, no further increase in clipping yield is predicted when leaf $\mathrm{N}$ concentration is increased beyond the critical concentration. In cases where a significant ( $\alpha=0.05$ ) linear plateau model could not be found, the plateau yield value was calculated as the mean of the six highest yields for that date. Deviations from plateau yields were calculated as the differences between yield and plateau yield for each date. These deviations were pooled across all sample dates and plotted against corresponding leaf $\mathrm{N}$ concentrations. Deviations from plateau yields compared with leaf $\mathrm{N}$ concentrations have been used to identify luxury consumption of $\mathrm{N}$ in corn (Zea mays L.) (Cerrato and Blackmer, 1991). A linear plateau model was generated on the pooled data. The same procedure was followed for CM1000 index and CIE hue measurements. For the greenhouse experiment, clipping yield, CM1000 index, and CIE hue were averaged across all dates and each was plotted against leaf $\mathrm{N}$ concentration. A linear plateau model was developed for each.

Leaf $\mathrm{N}$ concentrations from the field experiment were plotted against fertilizer $\mathrm{N}$ application rates, and a linear plateau model was developed for each date. On dates for which the plateau segment of the linear plateau model encompassed less than six data points or when a significant $(\alpha=0.05)$ linear plateau model could not be found, a linear model $[\gamma=a+b x]$ was used instead. For greenhouse data, leaf $\mathrm{N}$ concentration was related to fertilizer $\mathrm{N}$ application rate with a linear plateau model.

Linear and linear plateau models were generated with the REG and NLIN procedures in the Statistical Analysis Software (SAS) package (SAS Institute, 1999). All models were checked for homoscedasticity, normality of residuals, and independence of residuals (Tabachnick and Fidell, 2001).

\section{RESULTS AND DISCUSSION Clipping Yield, Hue, and CM1000 Response to Leaf Nitrogen}

Significant $(p<0.05)$ linear plateau models were found relating deviations from plateau values for clipping yield, CIE hue, and CM1000 index to leaf $\mathrm{N}$ concentration, for data pooled across sample dates, for the field experiment (Fig. 1). Critical concentrations in leaf $\mathrm{N}$ ranged from 30.0 to $33.3 \mathrm{~g} \mathrm{~N} \mathrm{~kg}^{-1}$ across clipping yield, CIE hue, or CM1000 index measurements. These values are within that suggested as a sufficiency range for turfgrass (Jones, 1980; Turner and Hummel, 1992), and is similar to the lower values in survey ranges and averages presented for Kentucky bluegrass, perennial ryegrass, and creeping red fescue (Mills and Jones, 1996). Our critical concentrations, however, are generally lower than maximum or average tissue $\mathrm{N}$ concentrations reported for Kentucky bluegrass (Liu et al., 1993; Frank et al., 2006), perennial ryegrass (Liu et al., 1993; Miltner et 
al., 2001), and mixed cool-season species turfs (Kopp and Guillard, 2002a). Tissue $\mathrm{N}$ concentrations greater than expected optimum ranges in these studies may be a result of luxury consumption of $\mathrm{N}$, differences in management practices, or differences in timing of tissue sampling.

Variability in our data close to the critical concentration in these plots (Fig. 1), however, may limit the usefulness of leaf $\mathrm{N}$ analysis in cases when leaf $\mathrm{N}$ is close to optimum (Cerrato and Blackmer, 1991). Approximate 95\% confidence intervals constructed for estimates of the critical concentrations from these models were 28.5 to $31.5 ; 30.3$ to 32.8 ; and 29.0 to 37.5 for clipping yield, CM1000 index, and hue, respectively (Fig. 1). These confidence intervals may give some further indication of reasonable optimum ranges considering the variability of the pooled data. Since our field experiment turf stand was of mixed species composition, the critical concentrations determined for this experiment might not be applicable to stands of single species, since optimum ranges may vary among turf species.

Significant $(p<0.05)$ linear plateau models were found relating mean clipping yield, mean CIE hue, and mean CM1000 index to leaf N concentration, for the greenhouse experiment (Fig. 2). Critical concentrations in leaf $\mathrm{N}$ ranged from 27.1 to $32.0 \mathrm{~g}$ $\mathrm{N} \mathrm{kg}^{-1}$ across clipping yield, CIE hue, or CM1000 index measurements. This range is similar to the sufficiency range for tissue $\mathrm{N}$ concentration suggested for turfgrass (Jones, 1980; Turner and Hummel, 1992), and similar to lower values in the survey range presented for Kentucky bluegrass (Mills and Jones, 1996). Our critical values are lower than values from studies reporting average tissue $\mathrm{N}$ values for $\mathrm{N}$ fertilized Kentucky bluegrass turfs (Wesley et al., 1988; Liu et al., 1993;

Frank et al., 2006; Liu and Hull, 2006). Differences in critical concentrations between our field and greenhouse studies were small, despite differences in species, management, and irrigation regime. The critical concentrations

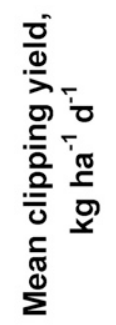
is indicated by $n$.
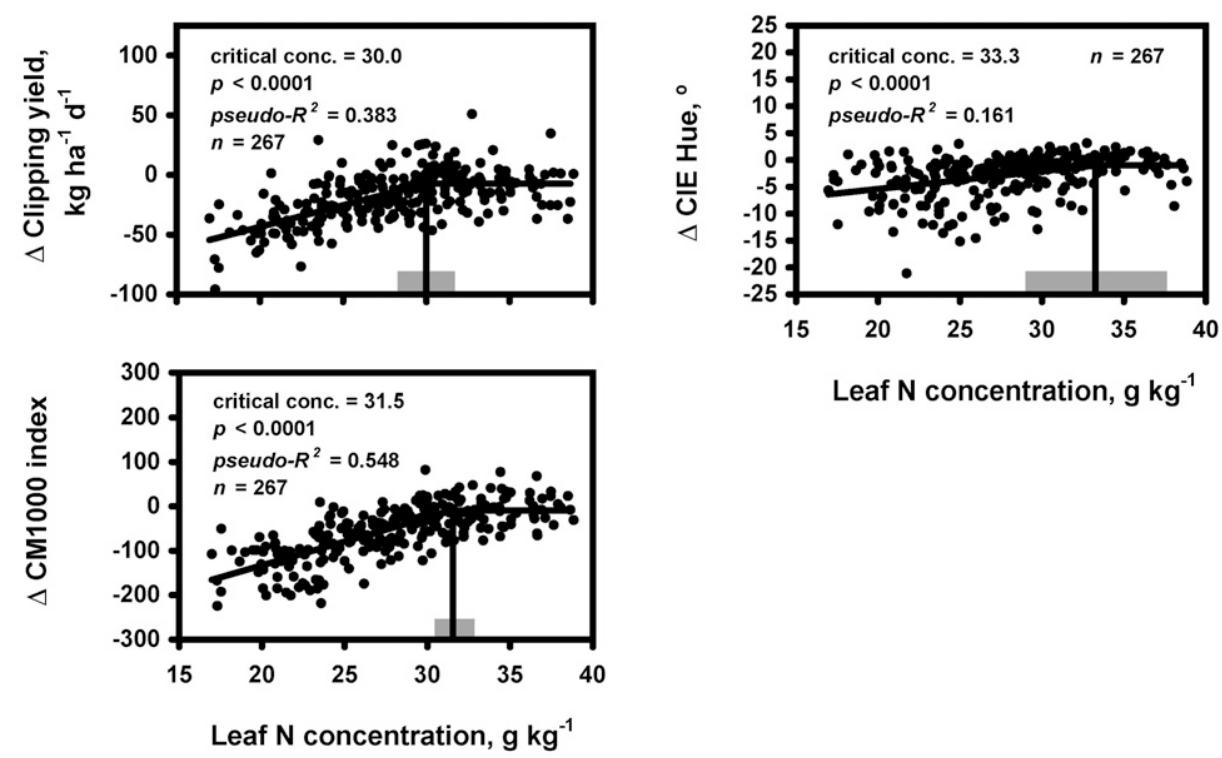

Leaf $\mathrm{N}$ concentration, $\mathrm{g} \mathrm{kg}^{-1}$

Figure 1. Deviations from plateau turfgrass clipping yield, Commission Internationale de I' Eclairage (CIE) hue, and CM1000 in relation to leaf N concentration for a mixed coolseason species lawn in Connecticut. Data are pooled from 10 sample dates across two growing seasons. Linear plateau models are shown. Critical conc. and vertical lines to the $x$ axes indicate critical concentrations from linear plateau models. Gray boxes on the $x$ axes indicate the extent of approximate 95\% confidence intervals for the critical concentrations. Number of observations per plot is indicated by $n$.
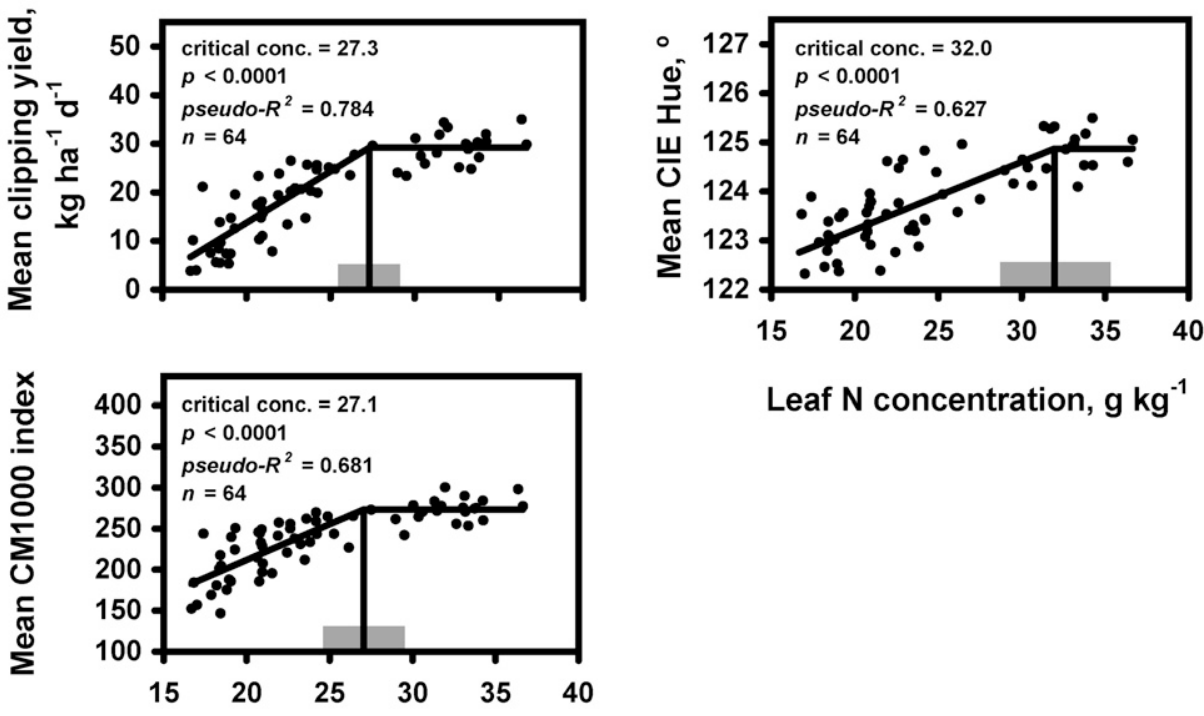

Leaf $\mathrm{N}$ concentration, $\mathrm{g} \mathrm{kg}^{-1}$

\section{Leaf $\mathbf{N}$ concentration, $\mathbf{g ~ k g}^{-1}$}

Figure 2. Mean turfgrass clipping yield, Commission Internationale de l' Eclairage (CIE) hue, and CM1000 in relation to leaf $\mathrm{N}$ concentration for greenhouse grown Kentucky bluegrass (Poa pratensis L.). Clipping yield, CIE hue, and CM1000 data are averaged from 24 sample dates across two growing seasons, and leaf $\mathrm{N}$ was determined on samples composited from 24 sample dates across two growing seasons. Linear plateau models are shown. Critical conc. and vertical line to the $x$ axis indicate critical concentrations from quadratic plateau models. Gray boxes on the $x$ axes indicate the extent of approximate $95 \%$ confidence intervals for the critical concentrations. Number of observations per plot

from our experiments did not differ much from minimum adequate tissue $\mathrm{N}$ concentrations for forage perennial ryegrass or forage Kentucky bluegrass (Kelling and Matocha, 1990; Pinkerton et al., 1997). 

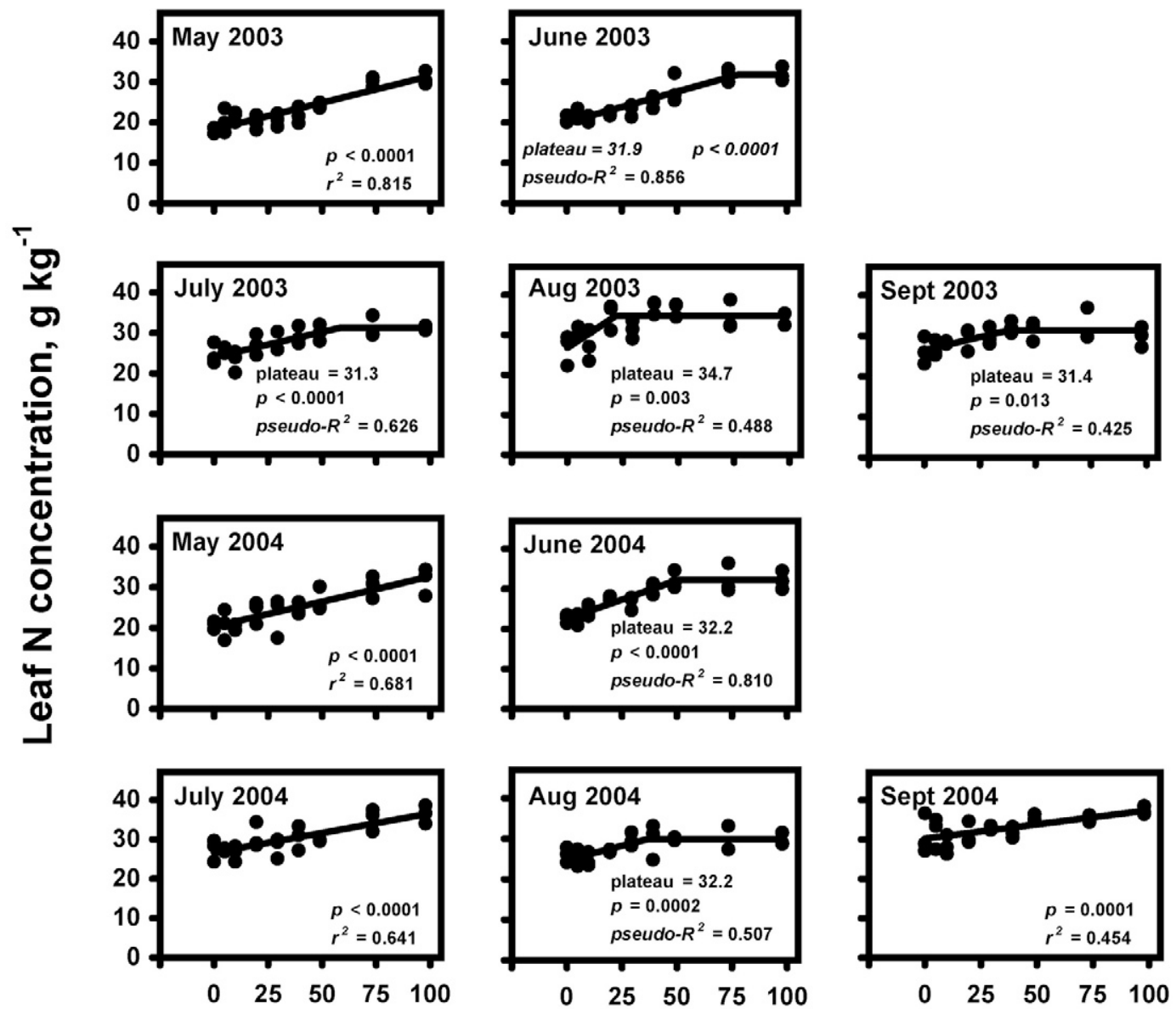

\section{$\mathrm{N}$ fertilizer rate, $\mathrm{kg} \mathrm{N} \mathrm{ha}^{-1} \mathrm{mo}^{-1}$}

Figure 3. Leaf $\mathrm{N}$ concentration in relation to $\mathrm{N}$ fertilizer application rate for a mixed cool-season species turfgrass lawn in Connecticut by sample date. $\mathrm{N}$ was applied in 6 mo each growing season, May through October, for a total of between 0 and $587 \mathrm{~kg} \mathrm{ha}^{-1} \mathrm{yr}^{-1}$. Linear plateau models are shown for sample dates for which significant $(p<0.05)$ models were found. Plateau indicates the plateau value from linear plateau models. On sample dates for which a satisfactory linear plateau model could not be found, a significant linear model is shown.

Turfgrass may have responses to available $\mathrm{N}$ other than the growth, color, and reflectance meter measurements explored in this study. Other turf responses include changes in stand density, disease incidence, or recovery from injury. These other responses were not investigated in this study, and their relationships to tissue $\mathrm{N}$ concentration may suggest critical concentrations different than those reported in this study.

\section{Leaf Nitrogen Response to Nitrogen Fertilizer Rate}

Significant $(p<0.05)$ linear plateau models were found relating leaf $\mathrm{N}$ concentration to fertilizer $\mathrm{N}$ application rate for 6 of 10 sample dates for the field experiment (Fig. 3). Significant linear models were found for the other four dates (Fig. 3). For linear plateau models, plateau values for leaf $\mathrm{N}$ ranged from 31.3 to $34.7 \mathrm{~g} \mathrm{~N} \mathrm{~kg}^{-1}$. The values of the plateaus from our study suggest that the low end of a recommended optimum range for leaf $\mathrm{N}$ concentration should not exceed about $31 \mathrm{~g} \mathrm{~kg}^{-1}$, since concentrations above this were not obtainable on some sample dates even with high fertilizer $\mathrm{N}$ rates, for the conditions of our study. Leaf $\mathrm{N}$ concentrations exceeded $31 \mathrm{~g} \mathrm{~kg}^{-1}$ notably on some sample dates (Aug. 2003, July 2004, Sept. 2004) (Fig. 3). Pooled data from our field experiment (Fig. 1) and greenhouse experiment (Fig. 2) included critical leaf $\mathrm{N}$ concentrations greater than $31 \mathrm{~g}$ $\mathrm{kg}^{-1}$, but an inspection of these figures suggests that marginal improvements in turf clipping yield, CIE hue, and CM1000 index will be small above about $30 \mathrm{~g} \mathrm{~N} \mathrm{~kg}^{-1}$ for each of our experiments. Prudence would recommend using lower critical concentrations from these experiments to avoid excess $\mathrm{N}$ fertilization. A critical concentration of $27.5 \mathrm{~g} \mathrm{~N} \mathrm{~kg}^{-1}$ corresponds to the lower end of the sufficiency range suggested for turfgrass (Jones, 1980; Turner and Hummel, 1992).

The reciprocal of the slopes of the linear segment of the linear plateau models and of the linear models relating leaf $\mathrm{N}$ concentration to $\mathrm{N}$ application rate (Fig. 3) give an indication of the amount of additional $\mathrm{N}$ fertilizer required to realize a marginal change in leaf $\mathrm{N}$ concentration. The reciprocal of these slopes ranged from 3.7 to 
$13.9 \mathrm{~kg}$ fertilizer $\mathrm{N} \mathrm{ha}^{-1} \mathrm{mo}^{-1}$ for each $\mathrm{g} \mathrm{N} \mathrm{kg}{ }^{-1}$ change in leaf $\mathrm{N}$ for our field experiment. The relatively small range in the reciprocal of these slopes suggests that a leaf $\mathrm{N}$ test for turfgrass can indicate the amount of $\mathrm{N}$ fertilizer recommended to apply for maximum turf response. However, further experiments would be needed to validate those recommendations.

A significant linear plateau model relating leaf $\mathrm{N}$ concentration to fertilizer $\mathrm{N}$ application rate was found for data from the greenhouse experiment (Fig. 4). The plateau value from this model was $33.1 \mathrm{~g} \mathrm{~N} \mathrm{~kg}^{-1}$, which falls within the range of plateau leaf $\mathrm{N}$ concentrations from the field experiment. The reciprocal of the slope of the linear segment of this linear plateau model (Fig. 4) was $4.7 \mathrm{~kg}$ fertilizer $\mathrm{N} \mathrm{ha}^{-1}$ $\mathrm{mo}^{-1}$ for each $\mathrm{g} \mathrm{N} \mathrm{kg}{ }^{-1}$ leaf $\mathrm{N}$. This value is within the range given for the field experiment, though differences in leaf $\mathrm{N}$ responses to fertilizer $\mathrm{N}$ application are to be expected with different turf species (Liu et al., 1993; Liu and Hull, 2006), soil, and management practices.

Plateau values of leaf $\mathrm{N}$ in response to fertilizer $\mathrm{N}$ rate (Fig. 3 and 4) exceeded critical concentrations of leaf $\mathrm{N}$ for yield on most sample dates (Fig. 2 for greenhouse, data not shown for individual sample dates for field). The difference in these values suggests that the turf in these experiments exhibited luxury consumption of $\mathrm{N}$; since at high fertilizer $\mathrm{N}$ rates, additional $\mathrm{N}$ fertilizer caused increases in leaf $\mathrm{N}$ concentration without corresponding increases in clipping yield, CIE hue or CM1000 index. The extent of this luxury consumption was small in our experiments, however. Differences between plateau $\mathrm{N}$ concentration and mean critical concentration for clipping yield ranged from -0.4 to $5.8 \mathrm{~g} \mathrm{~kg}^{-1}$ across sample dates and experiments (data not shown). Because we did not speciate leaf $\mathrm{N}$ into assimilated and unassimilated pools, however, our estimates for luxury consumption could include assimilated $\mathrm{N}$ that did not correspond to a response in growth. The relatively small extent of luxury consumption measured in this experiment may be related to our sampling protocol. Any unassimilated $\mathrm{N}$ stored in the leaf tissue would be removed by the one or two mowings before sampling.

Because models relating leaf $\mathrm{N}$ concentration to fertilizer $\mathrm{N}$ application rate included plateaus in leaf $\mathrm{N}$ at high $\mathrm{N}$ fertilizer rates (Fig. 3 and. 4), a leaf $\mathrm{N}$ test may not be able to identify sites with excess available soil $\mathrm{N}$, especially when tissue sampling is performed after turf has been mowed. When turf is actively growing and subjected to regular mowing, leaf $\mathrm{N}$ may represent chlorophyll, structural proteins, and enzymes largely associated with the photosynthetic apparatus, but little stored N. If this is the case, plateaus in leaf $\mathrm{N}$ concentrations with increasing fertilizer $\mathrm{N}$ rate may be a result of the genetic or environmental maximum for photosynthetic structure density in the turf leaves. Unassimilated $\mathrm{N}$ may be stored in plant structures other than the leaf. Apparent luxury consump-

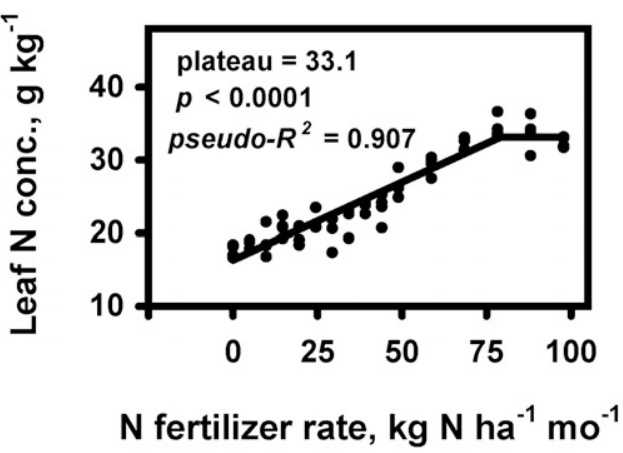

Figure 4. Leaf $\mathrm{N}$ concentration in relation to $\mathrm{N}$ fertilizer application rate for a greenhouse grown Kentucky bluegrass (Poa pratensis L.) turf. Leaf $\mathrm{N}$ was determined on samples composited from 24 sample dates across two growing seasons. $\mathrm{N}$ was applied in 6 mo each growing season, May through October, for a total of between 0 and $587 \mathrm{~kg} \mathrm{ha}^{-1} \mathrm{yr}^{-1}$. A linear plateau model is shown. Plateau indicates plateau value from linear plateau model.

tion of $\mathrm{N}$ in this study suggests that unassimilated $\mathrm{N}$ might be stored in the leaf under some conditions, though tissue analysis for total $\mathrm{N}$ cannot directly differentiate between assimilated and stored compounds. These considerations suggest that a test that is better able to differentiate stored $\mathrm{N}$ from assimilated $\mathrm{N}$ in plant tissue or which samples available $\mathrm{N}$ in the soil may be better able to identify sites with excess available soil $\mathrm{N}$.

\section{CONCLUSIONS}

Models relating turfgrass clipping yield, CIE hue, and CM1000 index to leaf $\mathrm{N}$ concentrations suggest that leaf $\mathrm{N}$ analysis could be used to separate turf sites with optimum leaf $\mathrm{N}$ from those with below optimum leaf $\mathrm{N}$. These models suggested a lower value for the optimum range for leaf $\mathrm{N}$ concentration of $30 \mathrm{~g} \mathrm{~kg}^{-1}$. This value differs only slightly with the lower end of the sufficiency range suggested for turfgrass (Jones, 1980; Turner and Hummel, 1992) but is lower than maximum or average values reported for tissue $\mathrm{N}$ by other studies. The disparity between sufficiency concentrations and higher leaf $\mathrm{N}$ concentration observed in some studies suggests that optimum levels cannot be determined by simply examining tissue $\mathrm{N}$ levels across $\mathrm{N}$ fertilizer rates. Ranges in leaf $\mathrm{N}$ concentrations reported in some literature should not be reinterpreted as optimum values. Calibration studies comparing turf growth or quality responses to tissue $\mathrm{N}$ concentrations are needed. Our turf exhibited luxury consumption, though only to a small extent. High tissue $\mathrm{N}$ concentrations reported by other studies may be a result of greater luxury consumption. Plateaus in leaf $\mathrm{N}$ concentration with increasing fertilizer $\mathrm{N}$ rate suggest that turf leaf $\mathrm{N}$ analysis will be unable to detect sites with excess available soil $\mathrm{N}$, at least with a similar leaf sample collection schedule as that used in this study. Considering this, the inclusion in an $\mathrm{N}$ management program of a test capable of detecting excess $\mathrm{N}$ in soil or plant tissue 
to complement tissue $\mathrm{N}$ testing would be desirable. Even though this study found similar critical concentrations in leaf $\mathrm{N}$ in both field and greenhouse experiments, further calibration studies are necessary across species, climates, and management practices before optimum leaf $\mathrm{N}$ values can be determined with confidence.

\section{Acknowledgments}

Funding for this research was supplied by the USDA Hatch Funds Act program, Northeastern Regional Association of State Agricultural Experiment Station Directors project NE-187 "Best Management Practices for Turf Systems in the East," and by the Connecticut Institute of Water Resources, NIWR proposal 2003CT24B, "Handheld light meters and anion exchange membranes to reduce the threat of water pollution from turfgrass fertilizers." We thank Dr. Thomas F. Morris and the anonymous reviewers for their suggestions with this manuscript.

\section{References}

Ball, D.F. 1964. Loss-on-ignition as an estimate of organic matter and organic carbon in non-calcareous soils. J. Soil Sci. 15:84-92.

Bowman, D.C. 2003. Daily vs. periodic nitrogen addition affects growth and tissue nitrogen in perennial ryegrass turf. Crop Sci. 43:631-638.

Bowman, D.C., and J.L. Paul. 1992. Foliar absorption of urea, ammonia, and nitrate by perennial ryegrass turf. J. Am. Soc. Hortic. Sci. 117:75-79.

Bowman, D.C., J.L. Paul, and W.B. Davis. 1989. Nitrate and ammonium uptake by nitrogen-deficient perennial ryegrass and Kentucky bluegrass turf. J. Am. Soc. Hortic. Sci. 114:421-426.

Cerrato, M.E., and A.M. Blackmer. 1991. Relationship between leaf nitrogen concentrations and the nitrogen status of corn. J. Prod. Agric. 4:525-531.

Collins, S.A., and D.W. Allinson. 2004. Soil nitrate concentrations used to predict nitrogen sufficiency in relation to yield in perennial grasslands. Agron. J. 96:1272-1281.

Davis, J.G., and P.H. Dernoeden. 2002. Dollar spot severity, tissue nitrogen, and soil microbial activity in bentgrass as influenced by nitrogen source. Crop Sci. 42:480-488.

Epstein, E. 1972. Mineral nutrition of plants: Principles and perspectives. John Wiley \& Sons. New York.

Frank, K.W., K.M. O'Reilly, J.R. Crum, and R.N. Calhoun. 2006. The fate of nitrogen applied to a mature Kentucky bluegrass turf. Crop Sci. 46:209-215.

Hunter, R.S., and R.W. Harold. 1987. The measurement of appearance. 2nd ed. John Wiley \& Sons, New York.

Jones, J.R., Jr. 1980. Turf analysis. Golf Course Manage. 48:29-32.

Keeney, D.R., and D.W. Nelson. 1982. Nitrogen-inorganic forms. p. 643-698. In A.L. Page et al. (ed.) Methods of soil analysis: Part 2, Chemical and microbiological properties. 2nd ed. SSSA Book Ser. 5. ASA, SSSA, Madison, WI.

Kelling, K.A., and J.E. Matocha. 1990. Plant analysis as an aid in fertilizing forage crops. p. 603-643. In R.L. Westerman (ed.) Soil testing and plant analysis. 3rd ed. SSSA Book Ser. 3. SSSA, Madison, WI.

Kopp, K.L., and K. Guillard. 2002a. Clipping management and nitrogen fertilization of turfgrass: Growth, nitrogen utilization, and quality. Crop Sci. 42:1225-1231.

Kopp, K.L., and K. Guillard. 2002b. Relationship of turfgrass growth and quality to soil nitrate desorbed from anion exchange membranes. Crop Sci. 42:1232-1240.

Kopp, K.L., and K. Guillard. 2005. Clipping contributions to nitrate leaching from creeping bentgrass under varying irrigation and $\mathrm{N}$ rates. Int. Turfgrass Soc. Res. J. 10:80-85.

Landschoot, P.J., and C.F. Mancino. 2000. A comparison of visual vs. instrumental measurement of color differences in bentgrass turf. HortScience 35:914-916.

Liu, H., R.J. Hull, and D.T. Duff. 1993. Comparing cultivars of three cool-season turfgrasses for nitrate uptake kinetics and nitrogen recovery in the field. Int. Turfgrass. Soc. Res. J. 7:546-551.

Liu, H., and R.J. Hull. 2006. Comparing cultivars of three coolseason turfgrasses for nitrogen recovery in clippings. HortScience 41:827-831.

Mangiafico, S.S., and K. Guillard. 2005. Turfgrass reflectance measurements, chlorophyll, and soil nitrate desorbed from anion exchange membranes. Crop Sci. 45:259-265.

Mangiafico, S.S., and K. Guillard. 2006. Anion exchange membrane soil nitrate predicts turfgrass color and yield. Crop Sci. 46:569-577.

McCrimmon, J.N., H.A. Mills, and K.J. Karnok. 1992. Effect of Nform on macronutrient and micronutrient concentration and uptake of creeping bentgrass. J. Plant Nutr. 15:1269-1289.

McGuire, R.G. 1992. Reporting of objective color measurements. HortScience 27:1254-1255.

Mills, H.A., and J.B. Jones, Jr. 1996. Plant analysis handbook II. MicroMacro Publishing, Athens, GA.

Miltner, E.D., G.K. Stanke, and P.A. Backman. 2001. Leaf tissue $\mathrm{N}$ content and soil $\mathrm{N}$ status following monthly applications of nitrogen fertilizer to fairway turf. Int. Turfgrass Soc. Res. J. 9:409-414.

Pinkerton, A., F.W. Smith, and D.C. Lewis. 1997. Pasture species. p. 287-346. In D.J. Reuter and J.B. Robinson (ed.) Plant analysis an interpretation manual. 2nd ed. CSIRO, Collingwood, Victoria, Australia.

Purcell, L.C., and C.A. King. 1996. Total nitrogen determination in plant material by persulfate digestion. Agron. J. 88:111-113.

Rodriguez, I.R., and G.L. Miller. 2000. Using a chlorophyll meter to determine the chlorophyll concentration, nitrogen concentration, and visual quality of St. Augustinegrass. HortScience 35:751-754.

SAS Institute. 1999. SAS OnlineDoc, version 8. SAS Inst., Cary, NC.

Tabachnick, B.G., and S.F. Fidell. 2001. Using multivariate statistics. 4th ed. Allyn \& Bacon, Boston, MA.

Trenholm, L.E., R.N. Carrow, and R.R. Duncan. 1999. Relationship of multispectral radiometry data to qualitative data in turfgrass research. Crop Sci. 39:763-769.

Turner, T.R., and N.W. Hummel. 1992. Nutritional requirements and fertilization. p. 385-439. In D.V. Waddington et al. (ed.) Turfgrass. Agron. Monogr. 32. ASA, CSSA, and SSSA, Madison, WI.

Wesley, R.W., R.C. Shearman, and E.J. Kinbacher. 1988. 'Park' Kentucky bluegrass response to foliar applied urea. HortScience 23:556-559. 